\title{
Surfaces
}

\section{Introduction to and Discussion Summary of Lin Yaofu's "Toward a Version of China: The Taiwan Experience"}

\section{Murray Krieger}

Volume 5, 1995

DEUXIÈME CONGRÈS INTERNATIONAL SUR LE DISCOURS HUMANISTE (1995)

SECOND INTERNATIONAL CONFERENCE ON HUMANISTIC

DISCOURSE (1995)

URI : https://id.erudit.org/iderudit/1065003ar

DOI : https://doi.org/10.7202/1065003ar

Aller au sommaire du numéro

\section{Éditeur(s)}

Les Presses de l’Université de Montréal

ISSN

1188-2492 (imprimé)

1200-5320 (numérique)

Découvrir la revue

Citer ce document

Krieger, M. (1995). Introduction to and Discussion Summary of Lin Yaofu's

"Toward a Version of China: The Taiwan Experience". Surfaces, 5.

https://doi.org/10.7202/1065003ar
Résumé de l'article

Dans le cadre du deuxième congrès international sur le discours humaniste, ce texte est une introduction à « Une version de la Chine : l'expérience de Taiwan » de Lin Yaofu, et rapporte les principaux pôles d'intérêt qui ont émergé au cours de la discussion.
Copyright (C) Murray Krieger, 1995

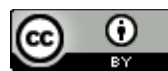

Ce document est protégé par la loi sur le droit d'auteur. L'utilisation des services d'Érudit (y compris la reproduction) est assujettie à sa politique d'utilisation que vous pouvez consulter en ligne.

https://apropos.erudit.org/fr/usagers/politique-dutilisation/ 


\section{Introduction to and Discussion Summary of Lin Yaofu's}

\section{"Toward a Version of China : The Taiwan Experience"}

Murray Krieger

University of California

Dept. of English

mkrieger@uci.edu

Surfaces Vol.V.208.1 (v.1.0A - 31/12/1995)

Copyright for texts published in SURFACES remains the property of authors. However, any further publication should be accompanied by an acknowledgement of SURFACES as the place of initial publication.

ISSN: $1188-2492$

\section{ABSTRACT}

In the context of the Second International Conference on Humanistic Discourse, this text introduces Lin Yaofu's "Toward a Version of China: The Taiwan Experience" and reports on the central concerns that emerged in its discussion.

\section{RÉSUMÉ}

Dans le cadre du deuxième congrès international sur le discours humaniste, ce texte est une introduction à "Une version de la Chine: l'expérience de Taiwan" de Lin Yaofu, et rapporte les principaux pôles d'intérêt qui ont émergé au cours de la discussion.

I am struck by the extent to which we can see Professor Lin's paper as extending some of the unresolved dialectical concerns that Wolfgang's and my summary of last year's meetings emphasized. Let me here suggest one Western scholar's reaction to that paper.

All of us must be confused by the cultural and linguistic confusions within Taiwan. For Taiwan presents a special combination of cultural and linguistic collisions, as well as collisions among different post-colonialisms. Professor 
Lin's paper dwells upon these fully. The sequence of colonialisms: China, Japan, and China again, though accompanied by strong recent intrusions of the West. These colonial impositions have been challenged, sometimes more forcefully and sometimes less, by desires for Taiwanese autonomy.

Professor Lin's paper reflects my own unsettling experiences among my friends in Taiwan, both in Taipei and Kaohsiung, in December 1994-friends representing a wide variety of political persuasions. It was an especially exciting and delicate time, since I was in Taipei right up to election day and returned shortly after. It was the first true multi-party election and displayed all the debate and controversy one can imagine.

What I discovered first was the strangely double and internally contradictory political structure that was being sustained in Taiwan: in Taipei there is, on the one hand, a president of the "Republic of China" (a continuing extension of the myth of one China and the regaining of the mainland), and there is also, on other other hand, a governor of the province of Taiwan (within a larger China), now going it on its own in independence from the mainland. At the moment, then, the "Republic of China" and Taiwan share an identical geographical area, though still acting as two political entities, one macro and one micro, each with its elected leader. This strange doubleness is a reflection of the linguistic and cultural problems surrounding perhaps the most complex network of postcolonial conflicts that our messy world presents to us today.

The Kuomintang (KMT) has been Taiwan's ruling party since its expulsion from the mainland and its subsequent takeover of Taiwan, presumably as a transition until its promised return to the mainland. The election represented the first time that the Kuomintang was seriously challengedand indeed it did lose a major election for the mayor of Taipei. The chief challenging party was the People's Democratic Party (PDP), a party whose platform called for an independent Republic of Taiwan, rejecting any future hope of a relationship with China. It thus seems to be the party of the native Taiwanese, by which I mean those whose family heritage antedated the takeover of the island by the (then) mainland Chinese upon their exodus from China in the late 1940s.

In reaction to the program of the PDP, a party to the right of the KMT emerged as the "New Party," one even more strongly resistant to any break from the Chinese tradition than was the KMT. Indeed, the New Party views the KMT as having, in recent years-after the deaths of Chiang and his sonbecome too compromising in its attempts to appeal to the Taiwanese. I must confess that I found it strange that people whom I would normally expect to find on the political left were now supporting the New Party because of their continuing desire for a reunion with China as well as their fear that the PDP platform's call for an independent Taiwan, once carried into action, would only provoke an attack and invasion from the mainland, from the People's Republic of China.

These political differences betray the uncertainties, and, beyond uncertainties, the central disagreements about both language and culture in Taiwan. The desire, represented by the PDP, to emphasize Taiwanese 
nationalism reflects one common reaction to the sequence of imperialistic takeovers of the island over the past century. Many Tainwanese view the invasion of their island by the armies of Chiang Kai-shek, in their flight from the mainland in the late 1940s, as more brutal in its abuses-even massacres-of the natives than the Japanese had been in their takeover many decades earlier. More recent memories, of course, tend to be more intense than those experienced by earlier generations. Some members of the PDP go so far as to reject their Chinese connections out of feelings that are pro-Japanese, with a nostalgia for the pre-World War II days on the island before the KMT tried, by means of any necessary oppressive acts, to remake the island in its own image. Many of the memories thought of as native Taiwanese are mixed with remnants of culture under Japanese domination. But there are disagreements about how many generations one must be removed from China in order to feel Taiwanese rather than one of the Chinese who are building another China until they can rejoin the Chinese of the mainland.

What, then, is to be the cultural identity of the island? Is the central culture, as well as the central language, to be indigenous Taiwanese, or Taiwanese as modified by imperial Japanese, or Taiwanese as modified by traditional imperial Chinese, or some regional version of mainland Chinese? Everyone, including-as is obvious-Professor Lin, has strong feelings about the choice. After tracing these alternatives very effectively, he comes down heavily on the side of the Chinese heritage, with an emphasis on classic Confucianism.

As we seek to expand upon the paper and extend it in order to relate it more specifically to our concerns of last year, I would suggest that our discussion revolve around some of the following issues: First, how can we relate various literary conventions to the several cultural potentials within the mixes I have discussed? During my visit I saw stunning contemporary paintings reflecting three quite different, and sometimes overlapping, traditions. Can we find anything similar in writing as well? Secondly, we can relate this discussion to last year's: how do these several traditions of writing, separately or in various mixtures, deal with relations among the several humanistic discourses, and especially the relation of the discourses of the arts-what we in the West call literature-to the others? What differences are there in dealing with these questions as we move from one cultural model in Taiwan to another? What are the resistances-and the conformities?

\section{Discussion}

Professor Lin began the discussion by expanding upon his paper and at the same time responded to my urgings by addressing the question: "What are humanistic discourses?" within his cultural tradition. His emphasis fell on his insistence that for Confucius-and thus for the tradition stemming from him-"humanistics is politics." Discourse-all the variety of discourses-are to move "from the individual to the world." To be a ruler is "to bring peaceutopia-to the world." So politics is everywhere there is discourse. (Professor Tay argued otherwise: that, although Buddhists find the gods of 
their religion in mainland traditions, thereby tying Taiwan and the People's Republic together, it is not Confucianism that they find.)

Professor Lin went on to discuss the problems surrounding the emergence of a new Taiwanese identity after summarizing again the history of the island as it grew out of the several colonialist moments that have defined it. There are special difficulties attending any attempt to work from an indigenous culture arising from the fact that the Taiwanese dialect has no mature writing system. What little there was had been outlawed by the Chiang Kai-shek regime. For the rest, there is resistance to Chinese even as they use it, although there are a few who insist on writing in Japanese. But even most of the group seeking radical independence write in Chinese even as they argue for a different written language. The most highly regarded Taiwanese authors produce a literature in Chinese that reflects Westernmainly American-as well as Chinese influences within a Taiwanese consciousness. Professor Lin concluded by expressing the doubt that any truly indigenous literature was likely to emerge, so strong has the assimilation into Chinese been.

Professor Lee gave the first of our group's responses by discussing the various proposals put forth for a newly constituted language, in effect a language by fiat, for the island's culture. At one extreme is the proposaldespite the radical differnces between a written language of characters and an alphabet language /pp. 8-9/ - to romanize the written language. At the other extreme is the proposal to introduce the Korean language. (Professor Tay added that the advent of computer technology increased the internationalization of computer language that may further encourage romanization.) Either alternative is in flight from Chinese in imitation of Korea's earlier successful attempt to create a new language responsive to its own needs. (Professor Wang described the origins of that language by means of a committee that was charged to write a collaborative poem to prove that a newly constructed Korean written language could work. And they succeeded.)

So, to summarize, the alternative proposed writing models listed by Professor Lee, are, aside from an obsolete Japanese, the retention of Chinese, a romanized version, Korean, and various mixes among these. He agreed with Professor Lin that the aboriginal Taiwanese, as a culture, has been just about extinguished, although, of course, there still are some remnants of a speech-dominated culture. The Chinese characters simply do not represent the Taiwanese dialect. And the oral language of the aboriginals has been hopelessly contaminated. Presently, Professor Lee added, the successful Taiwanese author writes in Chinese even while resisting the language of the oppressor and expressing that resistance. The Taiwanese identity struggles against the hegemony of Chinese characters that most Asian written cultures have felt. But it is a resistance in content, though not in style, which remains strictly and stubbornly Mandarin. Indeed, the written Chinese of Taiwan is not necessarily intelligible to other users of Chinese. An additional difficulty has been incurred by the fact that the Peoples Republic had legislated a changed and simplified version of Chinese written characters, a version not recognized on Taiwan. 
Professor Birus brought up what he saw as similar situations in both Vietnam and Turkey, in both of which a romanized alphabet was forcibly introduced, with major and in many ways unfortunate cultural consequences because of the cutting off of humanistic roots. The collision among Cyrillic, Arabic, and Roman alphabet systems in several Eastern former Soviet states is also a relevant comparison with what we are seeing in Taiwan, even where we do not have the special complications arising from differences between a written system based on characters and one based on an alphabet.

Professor Miller introduced the broader theoretical question immanent within the assumptions of these last phases of our discussion: are cultures language-determined? As a major counter-indication in the present case, he pointed out that the strong influences from the West, and especially the United States, seen in recent Taiwanese literary culture bear no relation to the language struggles we have been tracing. Here is an important element for our consideration that is outside all that has concerned us so far.

By way of response, Professor Lin reminded us that, as his paper and remarks indicate, each emerging culture, seeking to be conscious of its unique destiny, is sustained by a myth of its newness and originality even though it is largely a melange of the historical and foreign models it is applying.

Professor Iser commented on the assumption behind most of the alternatives discussed so far, the assumption that it should be a culture's mission to achieve an identity. This drive to create a single set of identifiable characteristics, he argued, is more American than European, perhaps because of the cultural heterogeneity of the United States. That heterogeneity leads to the hope of overcoming it, while the homogeneity of the several European cultures leads them to be less conscious of the need for such a drive. Is it the case that our reading of the present cultural struggles in Taiwan is shaped by our need to see them seeking identity?

Professor Adams introduced a far different, but persuasive, comparison: one between the striving for an indigenous culture in Taiwan and a similar striving in Ireland. Here are two island cultures, both of them the object of imperialistic takeovers that have threatened, or in some cases even precluded, the development of the native language and culture. The de Valera dynasty was all too much like Chiang Kai-shek's. Perhaps the call to fidelity to the Celtic (or perhaps to Catholicism) is much like the call to fidelity to Confucianism. The suppression of the indigenous language is also similar in the two cases, and with similar resistance and hence similar consequences for the writers. Of course such parallels also call our attention to the differences in the two cases, which could be discussed at length.

By way of qualifying this comparison Professor Yu pointed out that there are more still-unforeclosed possibilities for future developments in Taiwan, and fewer alternatives in Ireland, where the dilemma is of much longer standing and the options and the several hands in the game more limited.

Professor Miller ended our discussion by bringing us back to its theoretical significance: he suggested that we consider the degree to which any 
indigenous identity is a construct in the two cases of Taiwan and Ireland, as part of our concern with the role of construction in establishing the notion of identity in any language culture. While acknowledging that surely such an identity was more a product of construction in Taiwan than in Ireland, which, after all, had its own rich linguistic and cultural history, he reminded us that there is an element of construction-how strong, how controlling?in all our attempts in any culture to claim an identity.

Thus it may be that Taiwan is but an extreme example, contemporary and with important political overtones, of what every culture necessarily undergoes in trying to "discover" (that is, more candidly, to "create") what it is, or rather what it is to be. 